\title{
Subprime Mortgages, Foreclosures, and Urban Neighborhoods
}

\author{
Kristopher S. Gerardi and Paul S. Willen
}

\begin{abstract}
:
This paper analyzes the impact of the subprime crisis on urban neighborhoods in Massachusetts. The topic is explored using a dataset that matches race and income information from HMDA with property-level, transaction data from Massachusetts registry of deeds offices. With these data, we show that much of the subprime lending in the state was concentrated in urban neighborhoods and that minority homeownerships created with subprime mortgages have proven exceptionally unstable in the face of rapid price declines. The evidence from Massachusetts suggests that subprime lending did not, as is commonly believed, lead to a substantial increase in homeownership by minorities, but instead generated turnover in properties owned by minority residents. Furthermore, we argue that the particularly dire foreclosure situation in urban neighborhoods actually makes it somewhat easier for policymakers to provide remedies.
\end{abstract}

\section{JEL Classifications: D11, D12, G21}

Kristopher S. Gerardi is a research economist and assistant policy advisor at the Federal Reserve Bank of Atlanta. Paul S. Willen is a senior economist and policy advisor at the Federal Reserve Bank of Boston. Their email addresses are kristopher.gerardi@atl.frb.org and paul.willen@bos.frb.org, respectively.

This paper, which may be revised, is available on the web site of the Federal Reserve Bank of Boston at http://www.bos.frb.org/economic/ppdp/index.htm.

The views expressed in this paper are solely those of the authors and not necessarily those of the Federal Reserve Bank of Boston or the Federal Reserve System.

This paper was prepared for the UCLA-Berkeley Mortgage Meltdown Symposium, held October 30-31, 2008. We thank the organizers for suggesting the topic and our three thoughtful discussants, Mark Garmaise, Alexei Tehistyi, and Scott Frame for helpful suggestions. We are grateful to the Warren Group for the data and for assistance of all kinds, and to Julia Reade of the Supervision, Regulation, and Credit Unit of the Boston Fed for writing many of the programs used to perform the HMDA-Warren match, making possible much of the research discussed below.

This version: December 22, 2008 


\section{Introduction}

The wave of foreclosures of subprime mortgages that started in 2006 has disproportionately affected urban neighborhoods. Other communities have been affected as well, most notably the acres of new construction in places like greater Phoenix, the Central Valley in California, and Las Vegas. But the effects on already vulnerable inner-city communities have been profound. In this paper, we examine the causes and effects of the subprime crisis on these communities.

Our focus is on Massachusetts because we have exceptionally good data for that state. Our fundamental dataset is based on deed-registry data and includes every mortgage, foreclosure, and purchase and sale deed in Massachusetts going back to 1990. Each document is matched to a unique property, allowing us to construct a history of every homeownership experience from purchase to sale or foreclosure. To the deed-registry data we have matched information from the Home Mortgage Disclosure Act (HMDA) on the race and income of the borrower. Race is, of course, a central issue in urban neighborhoods and our data allow us to trace out the effects of subprime lending and the subsequent foreclosure crisis on different groups. The data details are in Section 3.

We start by examining the role of subprime lending in homeownership prior to the crisis. One of the purported benefits of subprime lending was that it increased access to credit, and therefore homeownership. Indeed, we see a large increase in the minority fraction of buyers in Massachusetts, coinciding with the peak of subprime activity. But we also find that there was a large increase in the minority fraction of sales, implying much smaller gains in minority homeownership rates than a naive analysis of the purchase data alone would suggest. Direct evidence on racial transitions, in fact, shows a significant increase in intraracial purchases, consistent with the idea that minority homeownership gains were positive during this period, but smaller than one would observe if looking only at the inflows to homeownership.

We then evaluate inner-city homeownerships and the foreclosure crisis. We focus on $2-4$ family dwellings (hereafter referred to as multi-family homes) because these are disproportionately located in urban areas, account for a disproportionate share of the foreclosures in Massachusetts, and have an obvious externality in the evictions of the tenants living in them when these buildings are foreclosed. ${ }^{1}$ The large number of foreclosures on these properties is not inconsistent with their performance in the last foreclosure wave in Massachusetts in

\footnotetext{
${ }^{1}$ These multi-family properties are sometimes owner-occupied, with the owner living in one unit and renting out the remaining units. We cannot distinguish between these cases and cases in which the owner does not occupy a unit. However, both of these situations involve the presence of tenants, and thus the collection of rental income, as well as the eviction problem described above in the event of foreclosure.
} 
the early 1990s, when there was no subprime market. However, subprime lending clearly played a role, as estimates of our empirical, homeownership termination model suggest that homes purchased with these types of mortgages are lost to foreclosure much more frequently than those purchased with prime mortgages. As evidence of this, we show that although the price fall in Massachusetts was less than half as big in this cycle (as of the end of 2007) as in 1988-93, the number of foreclosures was roughly the same.

We conclude by examining options for mitigating the crisis. We focus on proposals to reduce principal balances on mortgages as a way to reduce foreclosures. We argue, following Foote, Gerardi, and Willen (2008), that evaluation of such proposals must balance what we call Type I error, failing to assist people who need help, against Type II error, providing costly assistance to people who do not need help. In the data, for reasonable parameters, Type II error dramatically exceeds Type I error, making most principal reduction schemes economically infeasible. However, we argue that for multi-family homes purchased with subprime mortgages, the likelihood of foreclosure is so high -66 percent for our baseline specification - that Type II error is not a significant problem, and principal reduction schemes would have a higher probability of working.

The paper proceeds as follows. A literature review follows immediately after this section. In Section 3, we discuss the data. Section 4 evaluates the role of subprime lending in fostering minority homeownership. Section 5 focuses on the foreclosure crisis, and Section 6 concludes with a discussion of what, if anything, we can do to mitigate the crisis.

\section{Literature Review}

In this section we conduct a brief summary of the recent literature on this topic. We focus on studies that have analyzed both benefits and costs of increased minority and low-income homeownership. One of the issues that we highlight in this discussion is the large amount of ambiguity and uncertainty in the current literature regarding the actual social benefits of homeownership. While history has certainly shown that policymakers view homeownership as a welfare-enhancing state, the economic literature does not reach the same unanimous consensus. We also review some of the numerous studies that have looked at the role subprime mortgage lending has played in facilitating minority and low-income homeownership through the expansion of credit markets over the past decade. However, we also summarize analysis in the literature of the downside of subprime lending, which has focused on the higher mortgage defaults and foreclosures that have characterized these markets in recent times. 


\subsection{Trends in Minority Homeownership Rates and the Role of the Subprime Mortgage Market}

Homeownership rates for minority households have increased substantially over the past 60 years, with a good part of the increase coming over the past decade or so. In 1940, for example, the homeownership rate of black households was approximately 20 percent (Collins and Margo 1999). By 1994, the homeownership rate had increased to 42 percent, and in 2003, more than 48 percent of black households were homeowners (Gramlich 2004). Much of the increase in minority homeownership over the past decade has been attributed to an expansion of credit to borrowers without the financial means and/or credit histories to obtain financing through traditional credit facilities. This expansion of credit has, to a large extent, taken place through the subprime mortgage market (Gramlich 2007). The subprime mortgage market emerged in force in the early-mid 1990s. Its origins can be traced back to household financing companies of the 1970s and 1980s that specialized in debt consolidation and home improvement loans (N.H.S. 2004). With innovations such as credit scoring and automated underwriting, as well as changes in legislation such as the Tax Reform Act of 1986, which eliminated tax advantages of nonhousing consumer debt, risk-based pricing and the subprime lending industry became more mainstream (Apgar and Herbert 2005). The value of originations in the subprime mortgage market increased from $\$ 35$ billion in 1994 to over $\$ 600$ billion in 2005 and 2006 (Inside Mortgage Finance 2008).

Much of the rapid growth in the subprime mortgage lending industry has taken place in minority and low-income neighborhoods. Canner, Passmore, and Laderman (1999), using HMDA data, found that between 1993 and 1998, one-third of the growth in lending to Census tracts that are made up of predominantly minority households was due to increases in subprime lending (one-fourth for lower-income tracts). In a study of the Chicago mortgage market, Immergluck and Smith (1999) found that conventional, prime mortgage lenders were concentrated in higher-income, white areas, while subprime and FHA lending were concentrated in lower-income and minority neighborhoods. ${ }^{2}$ Calem, Gillen, and Wachter (2004) examined spatial variation in subprime lending in the Chicago and Philadelphia areas. Unlike many previous studies, they controlled for neighborhood risk measures as well as other neighborhood demographic characteristics and concluded that there was a strong concentration of subprime lending in neighborhoods with a large population of black homeowners. Mayer and Pence (2008) also found some evidence that subprime lending was more concentrated in zip codes with more black and Hispanic residents and lower levels of

\footnotetext{
${ }^{2}$ They also argued that the racial disparities in lending were too large to be explained by differences in credit histories.
} 
income. $^{3}$

Because of the numerous perceived benefits of homeownership for both individual households and local communities, which we discuss in more detail below, the expansion of credit through the development of the subprime mortgage market has been viewed by many as a positive development. There are many who do not share this view, however, and these observers largely cite predatory lending behavior on the part of many subprime lenders in creating unstable homeownerships. Most of the direct evidence of predatory lending is anecdotal in nature, while the indirect evidence basically looks at disparities between minority versus non-minority neighborhoods, and high-income versus low-income neighborhoods in the incidence of subprime lending, much like the literature reviewed above. ${ }^{4}$ However, since none of these types of studies can control for all household-level characteristics, especially credit histories, the interpretation of systematic predatory lending should probably be viewed with a healthy dose of skepticism.

\subsection{Benefits of Increased Minority and Low-Income Homeowner- ship}

At the household level, homeownership is believed to have both private and social benefits. Perhaps the most widely perceived economic benefit, especially for low-income households with little financial wealth, is through the process of "equity-building." ${ }^{5}$ The regular mortgage payments that accompany the purchase of a home are viewed by many as imparting discipline on households and serving as a form of forced savings. Implicit in this viewpoint is the belief that low-income households are not able to solve their optimal, life-cycle, consumption/savings allocation problem, perhaps as a result of a lack of financial sophistication or other behavioral causes such as time-inconsistent preferences. Also, implicit in this viewpoint is the belief that purchasing a home is a relatively low-risk investment. ${ }^{6}$ However, given the recent and historical volatility of local house prices, as well as various other factors, such as the timing of purchases and sales, which have a large impact on the financial returns to homeownership (Herbert and Belsky 2006), the opposite argument could easily be

\footnotetext{
${ }^{3}$ There are a few exceptions in the literature, such as Pennington-Cross and Nichols (2000) and Pennington-Cross (2002), who found that differences in housing prices, labor market conditions, and credit risk account for most of the variation in the incidence of subprime lending.

${ }^{4}$ See Harvey and Nigro (2004) for a brief literature review and evidence of the effect of anti-predatory lending laws.

${ }^{5}$ According to McCarthy, Zandt, and Rohe (2001), home equity makes up 44 percent of net worth of white households, and 61 percent for black and Hispanic households.

${ }^{6}$ See Flavin and Yamashita (2000) for a more detailed discussion of this topic in the context of a life-cycle model.
} 
made. In addition, repairs and maintenance must be considered in calculating financial returns to homeownership, and these are much more difficult for highly leveraged, low-income households to perform (Case and Marynchenko 2002). ${ }^{7}$

In additional to economic factors, there is evidence that the transition from renting to owning has positive social effects at the household level. These include better physical and psychological health and a greater level of overall happiness (Dietz and Haurin 2003). Some survey evidence suggests that homeownership positively affects family attitudes such as selfesteem and increases the likelihood of membership in local community groups (Rossi and Weber 1996). DiPasquale and Glaeser (1999) found that homeownership positively impacts citizenship. There has even been some evidence in the literature that homeownership has a positive impact on the educational outcomes of children (Green and White 1997).

But perhaps the most compelling argument that has been made by advocates of homeownership is the beneficial effect it has at the neighborhood level. The rationale is that homeownership gives individuals a stronger incentive to improve their community. Evidence has been found that homeowners participate more in the political system than renters (DiPasquale and Glaeser 1999) and are more likely to become involved in community activism in general (Cox 1982 and Rohe and Stegman 1994). A negative correlation between homeownership and the incidence of crime has been found by Alba, Logan, and Bellair (1994) and Glaeser and Sacerdote (1999). Finally, positive neighborhood externalities, resulting from the fact that homeowners often take better care of their homes than renters has been documented in the literature (McCarthy, Zandt, and Rohe 2001 and Mayer 1981).

While numerous empirical studies in the literature, many of which were discussed above, claim to have identified various social benefits from the transition to homeownership, an increasing number of recent studies have challenged these findings. These studies take the belief that homeownership is mistakenly identified as a causal factor of outcomes that are really derived from unobserved household characteristics. In other words, there is a selection effect into homeownership, which is not controlled for in many of these empirical studies, that is being conflated with, and interpreted as, a treatment effect. ${ }^{8}$ Aaronson (2000), an example of one such study, challenged the finding by Green and White (1997) that homeownership reduces the likelihood of a child's dropping out of school. Using an instrumental variables approach along with a more detailed list of covariates, Aaronson

\footnotetext{
${ }^{7}$ Another economic benefit of homeownership that should also be considered is its usefulness as a hedge against rent risk (Sinai and Souleles 2005). The intuition is that a renter faces year-to-year fluctuations in rental payments, while a homeowner is able to receive housing services at a set, nominal price. However, because of various mechanisms designed to stabilize volatility in rental payments that are in place for lowincome renters (such as rent controls), this consideration is likely of second or third-order importance for low-income households.

${ }^{8}$ We direct the reader to Dietz and Haurin (2003) for a more detailed discussion of this topic.
} 
found evidence that some of the effect found by Green and White is due to household-level characteristics that are difficult to measure, and much of the effect is actually due to the reduction in mobility that accompanies homeownership. ${ }^{9}$

This is an important debate in the literature, as the perceived social benefits to homeownership are used as the rationale for favorable tax policy with respect to homeownership, including the deductibility of mortgage interest, as well as other influential policies, such as the implicit subsidies provided to the government sponsored enterprises (GSE) in the housing market. If the social benefits are not as conclusive as previously believed, then it may be in our society's best interest for the government to re-evaluate these policies.

\subsection{Foreclosures and the Costs of Unstable Homeownerships}

In the previous section, we discussed the literature regarding the numerous potential benefits of increased homeownership rates. In this section we discuss some of the possible negative consequences of extending credit and advocating homeownership to households with little financial wealth and poor credit histories. There is evidence that these negative consequences occur not only at the household level, but may also adversely impact entire neighborhoods. As a result, there may be an important role for social policy to attempt to regulate the expansion of credit to the riskiest potential borrowers. This discussion is especially poignant given the recent foreclosure crisis and the overall state of current U.S. housing markets. One interesting question that policymakers now face is, to what extent has the destruction of minority and low-income homeownerships from foreclosure during the recent crisis offset their previous gains in homeownership over the past decade or so.

It is now taken as a stylized fact in the literature that homeowners using the subprime mortgage market to finance their home purchases default on their mortgages at a significantly higher rate than borrowers who use the prime mortgage market. Gerardi, Shapiro, and Willen (2007) using data from 1990-2007, estimate that over a fairly long horizon (approximately 12 years), borrowers who purchase their homes with subprime mortgages have an almost 20 percent chance of losing them to foreclosure - about 7 times as great as those who use the prime mortgage market. Immergluck and Smith (2004) found that subprime lending was the most important determinant of neighborhood foreclosure rates in the Chicago metropolitan area. At the neighborhood level, they estimated that for every 100

\footnotetext{
${ }^{9}$ Most studies that have analyzed this topic agree that homeownership substantially reduces mobility for virtually all households. The most common explanation is that transactions costs are much higher for homeowners than for renters (Haurin and Gill 2002). Other studies have shown that mortgage valuation plays a role in the effect of homeownership on mobility, through what has been termed the "mortgage lock-in" effect (Quigley 1987). Additional explanations include loss-aversion (Genesove and Mayer 2001) and tax considerations (Lundberg and Skedinger 1998).
} 
additional subprime mortgages from 1996 to 2001, there were an additional 9 foreclosure starts in $2002 .^{10}$

The exact cause of the high correlation between subprime lending and subsequent foreclosures is to some extent still an open question. There is significant evidence pointing to a selection effect, as many studies have found that borrowers who use the subprime mortgage market have characteristics that have been shown to induce higher rates of default, such as poor credit histories, high initial loan-to-value ratios, and high debt-to-income ratios. In other words, these borrowers are more likely to default because they have a history of delinquency (perhaps providing a signal of their preferences) or lack the financial means to survive an adverse financial shock or life event. In addition, because these borrowers are more leveraged on average compared with prime borrowers, in the event of both an adverse shock and a house price decline like the one we have recently experienced, they will have fewer alternative options to foreclosure, such as refinancing their mortgage, or selling their home. ${ }^{11}$

There is also a potential treatment effect, as subprime mortgages often carry significantly higher interest rates, which, other things being equal, result in higher monthly mortgage payments. In addition, a larger percentage of subprime mortgages than prime mortgages contain prepayment penalties, and this may also increase default probabilities. There has been little evidence of how important such a treatment effect is quantitatively, and the evidence that has been found points to a fairly small effect. ${ }^{12}$ It is important to realize, though, that separating the selection effect from the treatment effect and quantifying the contribution of each to observed increases in foreclosure rates is a very difficult endeavor, and we would argue that this has yet to be successfully accomplished in the literature.

Regardless of the channel by which subprime lending leads to increased incidence of foreclosure, the fact remains that this correlation is strong in the data. The adverse impacts of foreclosures on the individual household as well as on the surrounding community have been well documented in the literature. There are both financial and non-monetary costs of foreclosure that are borne by households. Perhaps the most important financial cost, beyond the loss of accumulated equity, is restricted access to future credit markets. ${ }^{13}$ Nonmonetary costs include the psychological hardship that goes along with losing one's home, which can often lead to adverse effects on family life, such as divorce or health problems.

\footnotetext{
${ }^{10}$ Other examples of studies that have documented elevated delinquency and foreclosure rates for subprime mortgages are Crew-Cutts (2003), and HUD (2000).

${ }^{11}$ See Gerardi, Shapiro, and Willen (2007) for a more detailed discussion.

${ }^{12}$ For example, it has been shown that resets of adjustable-rate, subprime mortgages, have not contributed significantly to increased foreclosure levels (Mayer, Pence, and Sherlund 2008; Foote, Gerardi, Goette, and Willen 2008a; and Pennington-Cross and Ho 2006).

${ }^{13}$ Moreno (1995) estimates that the average loss to a family experiencing foreclosure is $\$ 7,200$.
} 
There is also some evidence that under certain scenarios foreclosure can have negative externalities at the neighborhood level. These externalities are probably the strongest in poor, urban neighborhoods during a housing downturn, when clusters of vacant, neglected properties develop from widespread foreclosures. Research has shown negative correlations between clusters of foreclosures and increased criminal activity and lower neighborhood property values. ${ }^{14}$

Thus, the existing literature tells us about both an upside and a downside to the rapid rise in subprime mortgage lending. On the one hand, evidence suggests that the subprime market has provided opportunities for underprivileged households to become homeowners, and society has come to view homeownership as a welfare-enhancing state. We have briefly summarized a vast literature that has found substantial evidence of a wide variety of benefits from homeownership, although recently some of the methods and interpretations of these studies have come under fire. On the other hand, the subprime market has created many potentially unsustainable ownerships, since it has allowed borrowers with poor credit histories, little to no financial wealth, and unstable income streams to become homeowners. This, in turn, has resulted in widespread foreclosures nationwide.

\section{Data}

We merge two sources of data in this paper. The first source is property and mortgage transaction files obtained from Massachusetts county-level, registry of deeds offices by the Warren Group, a private corporation that specializes in collecting residential property records in the northeastern states. These data contain residential purchase/sale deeds, mortgage originations, and foreclosure documents for the entire state of Massachusetts, going back to 1990. The second source is loan-level data collected under the Home Mortgage Disclosure Act (HMDA). These data contain some detail regarding loan and borrower characteristics. In this section, we briefly describe each data source and our methods for merging the two datasets.

\subsection{Warren Data}

The deed-registry data from the Warren Group include virtually every residential sale deed, including foreclosure deeds, and every mortgage, including second and third mortgages (as

\footnotetext{
${ }^{14}$ These effects are extremely difficult to identify in the data, but some examples of studies that have tried are Immergluck and Smith (2006), Dubin (2008), Harding, Rosenblatt, and Yao (2008), and Rogers and Winter (2008).
} 
well as home equity lines of credit) originated in the state of Massachusetts from January 1990 through December 2007. These data contain transaction amounts and dates for mortgages and property sales. They also include information about foreclosure deeds, which signify the very end of the foreclosure process, when the property is sold at auction to a private bidder or to the mortgage lender. However, the data do not contain detailed information on mortgage terms or borrower characteristics. The exact identity of the mortgage lender is included in the data, and we use this piece of information, in conjunction with information from the Department of Housing and Urban Development, in our analysis to construct indicators for mortgages that were originated by subprime lenders.

With these data we are able to construct a panel dataset of homeowners. We follow each homeowner from the date when he or she purchases the property to the date when he or she sells the home, loses it to foreclosure, or reaches the end of our sample. We use the term "ownership experience" to refer to this interval. ${ }^{15}$ The data also allow us to construct a collection of quarterly, repeat-sales price indexes at the town level, using the methodology of Case and Shiller (1987).

\subsection{HMDA Data}

We use HMDA data for Massachusetts from 1998 to 2006. These data contain certain characteristics of borrowers and properties of loans that are collected by mortgage lenders at the time of origination. For example, the HMDA data contain information about the borrower's race, income, gender, location (Census tract), and occupancy status. In addition the data contain some detailed characteristics of the mortgage and the lender, such as name of the lender, the type of lending institution, the amount of the mortgage, the date of origination, and information about the lien status. The HMDA data provide broad coverage of U.S. mortgage markets. In 2006, for example, approximately 8,900 lenders reported HMDA data, accounting for about 80 percent of all home lending nationwide (Avery, Brevoort, and Canner 2006).

\subsection{Matched Sample}

We merge mortgages in the deed-registry data with mortgages in the HMDA data between 1998 and 2006. The merge is based on the dollar amount of the mortgage, the Census tract where the borrower lives, the identity of the mortgage lender, whether the mortgage

\footnotetext{
${ }^{15}$ For more details regarding the construction of the dataset, we direct the reader to Gerardi, Shapiro, and Willen (2007).
} 
was a refinance or for a purchase, and finally the date of the mortgage. ${ }^{16}$ We were able to match about 60 percent of the mortgages in the Massachusetts registry of deeds data (the population of mortgages) to the HMDA data each year. Considering that HMDA does not have perfect coverage of the mortgage market, the match rate is actually better than 60 percent. Furthermore, since we are not conducting a loan-level analysis, it is not the individually matched mortgages that we care about per se. Rather, we are conducting our analysis at the level of the ownership, and, thus, to obtain some of the time-invariant borrower characteristics from HMDA, such as race, we need only match one mortgage in the ownership. For example, if there is a homeowner who obtains three mortgages while living in the same property, in order to obtain the race of the household we only need to match one of the three mortgages.

Table 1 contains statistics for the percentage of ownership experiences to which we were able to match HMDA information (fourth column). The match percentage fluctuates from just over 70 percent for ownerships initiated in 1998 to almost 75 percent in 2001 . The last column contains the percentage of ownerships initiated each year for which we are able to assign a racial designation from the HMDA data. This is typically 5 to 7 percentage points lower than the overall match rate, as a result of discrepancies in the HMDA race variable. ${ }^{17}$

The second panel of Table 1 contains statistics for the percentage of sales, excluding foreclosures, that we were able to match with HMDA data. These percentages are substantially lower than the purchase percentages, as we cannot match any sales for homeownerships initiated before 1998 for which there was not a refinanced mortgage after 1998. We managed to obtain HMDA information for approximately 40 percent of Massachusetts sales after 2002, but for sales before 2002, the percentages are quite low. Finally, the last panel of Table 1 contains the corresponding statistics for foreclosure deeds. From 2005 to 2007, the match rate is very high. This is because most recent foreclosures occurred on ownerships that were either initiated after 1998, or had refinanced their mortgage at least once (often

${ }^{16}$ The date poses a small problem, as this variable is not consistent across both datasets. In the HMDA data, the date that the mortgage was originated is listed. However, in the registry of deeds data, the date that the mortgage was recorded at the registry is listed. These two dates are usually different. Thus, when performing the match, we use a date range of 45 days - the recording date is allowed to be up to 15 days before the date of origination, and 30 days after. The recording date is usually a few days after the origination date, but we found some instances where we were sure that the mortgages were the same, and the recording date was before the listed origination date in HMDA. To perform the match, we used the PROC SQL function in SAS 9.0.

${ }^{17}$ There are many instances of ownership for which we were able to match multiple mortgages but for which the race variable was not consistent. We threw many of these ownerships out of the dataset, unless closer inspection revealed an obvious assignment. For example if 4 out of 5 matched mortgages for a given ownership listed race as black, while the remaining mortgage listed a different race, we assumed the household was black. In addition, there were many instances in which the race of the household taking the mortgage was not determined in the HMDA data. 
many times) after 1998. Thus, we have very good coverage of race for borrowers who have recently experienced a foreclosure, as the majority of recent foreclosed ownerships show up in our sample of HMDA data.

\section{Homeownership and Subprime Lending}

Even critics of the subprime market have acknowledged its role in providing more opportunities for Americans to own homes. As discussed above, many have cited the record high levels of homeownership achieved in recent years as evidence of the benefits of expanded credit. In particular, subprime lenders extended credit to many minority groups that have historically had low homeownership rates. In this section, we show that the evidence for the beneficial role of subprime lending in increasing homeownership rates among disadvantaged minority groups in Massachusetts is less clear than it seems.

Figure 1 shows the main evidence of the beneficial role of subprime lending. The middle and lower panels show new home purchases for black and Hispanic households, respectively, from 1998, when the the subprime market was in its infancy, to 2006. The data present an impressive picture, as the number of black and Hispanic households who purchased homes more than doubled. ${ }^{18}$ This did not result from an increase in the number of homes purchased in the population as a whole (which did not change much, as the top panel shows), nor, as Census data show, from changes in the share of either black or Hispanic households or from an increase in young black or Hispanic households in the population. Instead, the pictures suggest a starring role for subprime mortgage lending. If we restrict our attention to homes purchased with prime mortgages, we actually see little or no change in minority purchase activity. The entire increase in purchases by both black and Hispanic households in Massachusetts over this period appears to result from the presence of the subprime market. Figure 2 contains further evidence of the concentration of subprime lending in inner-city, minority neighborhoods. The figure shows the spatial distribution of subprime purchases in Boston for two different time periods: 1998 to 2002 and 2003 to 2006. From the figure, there appears to be significant clustering of subprime purchase lending in minority-dominated areas of the city.

But the effect of increased minority home purchases on minority homeownership rates is not nearly as clear as it appears. The reason for this is that we are actually not interested in purchases per se, but rather in the increase in the stock of minority homeowners. While

\footnotetext{
${ }^{18}$ The subprime share of both black and Hispanic household purchases increased from approximately 6 percent in 1998 to almost 44 percent in 2005. The share of subprime purchases in Massachusetts increased more modestly for white households, from just over 2 percent in 1998 to 12.5 percent in 2006.
} 
the number of purchases and the stock of homeowners are related, the number of sales must also be taken into consideration. In other words, to measure the change in the stock of homeowners accurately we need to distinguish between gross and net flows into and out of homeownership.

When a household purchases a home, we call it a homeownership initiation, and when it sells the home or loses it to foreclosure, we call it a homeownership termination. The sum of all initiations by a particular group is the gross flow of that group into homeownership, and equivalently, all terminations by that group yield the gross flow out of homeownership. The key here is that we are interested in net flows into homeownership, which are the difference between initiations and terminations.

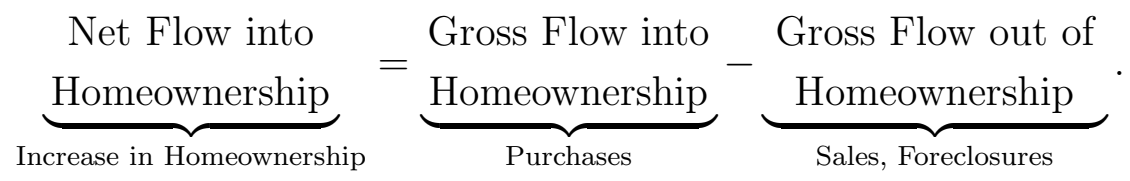

The data shown in Figure 1 provide information only about purchases, and thus gross flows into homeownership. In the absence of information about terminations, this tells us nothing about increases in homeownership rates. A reasonable assumption might be that terminations remained stable throughout this period, in which case we could reasonably imagine that a significant increase in minority homeownership took place. However, we will argue below that this assumption is not supported in the micro-data.

Our matched sample of HMDA and the Massachusetts deed-registry data provides a window into both initiations and terminations and thus provides insight regarding the net flows into homeownership during this period. In particular, for a subset of homeownerships, we are able to identify the race of the seller (or the foreclosee). This allows us to compare the fraction of minority households in the flow into homeownership with the fraction of minority households in the flow out of homeownership during a particular period. If the subprime mortgage market led to a substantial increase in minority homeownership, then we would expect to see that the increased fraction of home purchases accounted for by minorities would not be offset by an increased fraction of homeownership terminations by this same group. ${ }^{19}$

In performing these calculations, we focus on the share of transactions in our matched sample in a particular year, rather than the share of transactions in the sample as a whole. In other words, Figure 3, shows that in 2002, black households accounted for about 3.5 percent of the initiations for which we can identify the race of the buyer, and 2.6 percent of

\footnotetext{
${ }^{19}$ We cannot account for minority households that sell and then move to another state, but we have no reason to believe that this is a significant issue.
} 
the terminations for which we can identify the race of the seller or foreclosee. On the one hand, this solves the issue of the coverage of our matched sample growing over time, but it does not solve the potential problem of the composition of our matched sample changing over time.

Figure 3 shows that increasing terminations did indeed largely offset the increased homeownership initiations among black and Hispanic residents of Massachusetts. For black households, the rise in terminations appears to have largely offset the increase in purchases, while for Hispanic households, the offset is slightly less. Note that for both minority groups, net flows were positive for the entire period, so homeownership was increasing for both groups. What the data do show is that for black households, the dramatic increase in subprimefinanced purchases between 2003 and 2006 in Massachusetts was unlikely to have led to a significant increase in homeownership.

Figure 3 also shows an ominous change in the pattern of terminations. For both black and Hispanic households, almost all of the terminations through 2005 were sales, but in 2006 this began to change, as the fraction of terminations accounted for by foreclosure increased dramatically. By 2007, almost half of the terminations for black homeownerships came through foreclosure, although based on the evidence we have, net flows into homeownership remained positive for black households, even in 2007.

For a subset of the property sales in our data, we are able to identify the race of both the buyer and the seller. This information provides some insight into why such a large increase in purchases yielded only small gains in homeownership. To understand why these data are useful, assume that there is no change in the racial composition of the population, and no subdivision of existing property. In this case, for households in one group to increase their homeownership rate, they must purchase properties from a different group of households. In our data, there do appear to have been a significant number of interracial transactions, but this number increased only modestly in the period of high subprime activity. Table 2 shows these results. We focus first on multi-family homes because they provide a disproportionate amount of the housing in poor neighborhoods in Massachusetts, as we discuss in greater detail below. For these properties, interracial sales accounted for 27 percent of the transactions between 1998 and 2002. In the period of high subprime activity between 2003 and 2006, this share rose slightly to 30 percent. Throughout the sample period, approximately 75 percent of sellers were white. What these data tell us is that there was a steady shift of ownership of multi-family properties to minority groups, but that the subprime market had little effect on the pace of that shift. The results for single-family dwellings are broadly similar.

Another way to see this is to focus on intraracial transactions, also shown in Table 
2. Over the sample period intraracial sales accounted for between 70 and 73 percent of transactions. However, between 1998 and 2002, 27 percent of multi-family intraracial sales were between minority households, while between 2003 and 2006 this percentage increased to 36 percent. Thus, the subprime market seems to have largely facilitated an increase in the proportion of intraracial transactions involving minorities. In other words, one could argue that it enabled a sort of churning of properties. ${ }^{20}$

Altogether, the data seem to paint a somewhat bleak picture of the role of subprime lending in Massachusetts urban neighborhoods. Rather than increasing the share of homes owned by members of the community, it appears that subprime lending allowed one set of minority homeowners to replace another. Below, we show that these new homeowners, with greater debt burdens and less equity (and likely poorer credit to begin with), were poorly suited to handle the collapse in house prices that followed.

\section{Subprime Lending, HPA, and Foreclosures}

One of the striking observations from Figure 3 is the sudden and severe fall in the share of minority homeownership terminations accounted for by sales, beginning in 2005. This implies that the share of terminations accounted for by foreclosures is increasing substantially for minority households. In this section, we look more closely at this rise in foreclosures, and in particular, we focus on the role of subprime purchase lending and the substantial fall in house price appreciation during this recent period.

The second panel of Figure 4 shows the spatial distribution of foreclosures in Boston in 2007. If it were not for the labels, it would be difficult to distinguish this figure from Figure 2. In the current housing crisis, foreclosures are highly concentrated in minority neighborhoods, even relative to past foreclosure booms, such as the crisis of the early 1990s. The first panel of Figure 4 shows the location of Boston foreclosures in 1992. While there was also clustering of foreclosures in minority neighborhoods during that crisis, it was not quite as pronounced as in $2007 .{ }^{21}$

Table 3 contains more detailed information regarding the risk characteristics of the recent minority subprime purchases discussed above in connection with Figure 1. The

\footnotetext{
${ }^{20}$ The assumption that there was no subdivision and no major change in the composition of the population does not materially affect the results. The issue with subdivision is that new construction will show up in our data as subdivision and then as sales of existing properties. We might mistakenly count a homeownership as terminated if, for example, a black homeowner subdivided and sold part but not all of his property. Inspection of the data, and the limited amount of new construction in the state in this period, suggest this is not a problem.

${ }^{21}$ Part of this difference is likely due to the contribution of condominiums to the previous foreclosure crisis in Massachusetts, as condominiums were, for the most part, not located in minority neighborhoods.
} 
second and third columns in the table contain the median ratio of mortgage debt to income at purchase (DTI), and the median initial, cumulative loan-to-value ratio (CLTV ${ }^{22}$ for ownerships financed by a subprime mortgage for each year in our sample period. There are a couple of noteworthy observations from this table. First, both median DTI and CLTV ratios for all subprime ownerships increased over the sample period. The DTI ratio increased more dramatically for black and Hispanic subprime borrowers than for white borrowers. The median CLTV ratio for all borrowers increased by similar amounts, and reached 100 percent in 2005. Thus, the median subprime borrower in 2005 (both white and minority) was fully leveraged, and had basically invested nothing in the property at the time of purchase. The second interesting observation that can be made from the table is that subprime minority ownerships appear to be characterized by riskier attributes than white subprime ownerships. The CLTV ratios of minority subprime ownerships were slightly higher on average over the course of the sample than those of white subprime ownerships, while the DTI ratios were significantly higher.

The difference in risk attributes is certainly borne out in the relative foreclosure rates of minority versus white subprime ownerships. The first column in each panel of Table 3 shows the cumulative percentage of subprime ownerships that end in foreclosure. There are substantial differences between minority and white ownership vintages. For example, approximately 15 percent of black, subprime ownerships initiated in 2005 ended in foreclosure by December 2007, compared with 10 percent of Hispanic subprime ownerships, and 6.5 percent of white subprime ownerships. ${ }^{23}$ Below, we study the determinants of the rapid rise in foreclosures over our sample period that is obvious from Table 3.

\subsection{Multi-Family Analysis}

In this section, we take a closer look at the determinants of foreclosure, focusing on Massachusetts multi-family properties. Multi-family properties are very common in northeast housing markets. ${ }^{24}$ Often the owner of the property will live on one side, or one floor of the home, and will rent the remaining space to tenants. Multi-family homes make up approximately 10 percent of the state's housing stock, but in recent years they have accounted for a disproportionate number of the foreclosures in Massachusetts. This is apparent from Figure 5. In 2007, this type of home accounted for almost half of the foreclosures statewide. This is certainly part of the reason for our focus on multi-families; the other reason is a particular

\footnotetext{
${ }^{22}$ The loan-to-value is cumulative in the sense that it takes into account all liens on the property.

${ }^{23}$ These percentages are extremely high when one considers the severe censoring problem inherent in these calculations.

${ }^{24}$ The term "triple-decker" is often used in referring to this type of property.
} 
negative externality often associated with these properties. In the event of a foreclosure, the homeowner (if the house is owner-occupied) and all of the tenants are thrown out of the house. Thus, a multi-family foreclosure adversely affects families who have little to do with whether or not the mortgage is paid.

In Massachusetts, multi-family properties are largely found in the larger cities, and often in the lower-income, economically depressed, inner-city neighborhoods. Figure 6 shows the spatial distribution of multi-family homes in the state. Most of the multi-families are located in the larger cities in the eastern part of the state (the exception being Springfield, which is located in the western part of Massachusetts). Table 4 displays the 10 cities and towns in Massachusetts with the most multi-family property purchases over our sample period. ${ }^{25}$ These 10 communities accounted for almost half of the multi-family purchases from 1998 to 2006. The table also provides rankings of the cities in terms of population, income, and the fraction of minority households. It is apparent that these are relatively poor, and heavily minority-populated areas.

To analyze the determinants of multi-family foreclosures, we use a competing risk, proportional hazard model that is fairly standard in the literature. ${ }^{26}$ However, rather than model mortgage termination, we model ownership termination. Thus, the three possible termination states are: sale, foreclosure, or censored (as compared with prepayment, foreclosure, or censored in the case of modeling mortgage termination). ${ }^{27}$ We use our HMDAmatched ownerships, and data through December 2007. The list of explanatory variables includes both individual-level and more aggregated variables. The individual-level variables include the race of the homeowner (black, Hispanic, white, or other race), the ratio of nominal mortgage debt to income at the time of purchase, the occupancy status of the homeowner, an indicator constructed using the Department of Housing and Urban Development's (HUD) subprime lender list of whether the borrower financed his home purchase with a mortgage from a subprime lender, and the equity position of the homeowner, which is calculated by combining the initial cumulative loan-to-value ratio (CLTV) with cumulative house price appreciation experienced since purchase in the town where the house is located. To calculate HPA, we construct a set of town-level, repeat-sales price indexes using the Case-Shiller methodology (Case and Shiller 1987). The equity measure is given by the formula:

$$
E_{i t}=\frac{\left(1+C_{j t}^{H P A}\right)-C L T V_{i 0}}{C L T V_{i 0}},
$$

\footnotetext{
${ }^{25}$ There are 351 cities and towns in the state of Massachusetts.

${ }^{26}$ The specification is similar to that of Deng, Quigley, and Order (2000).

${ }^{27}$ For details on the exact model specification see Gerardi, Shapiro, and Willen (2007).
} 
where $C L T V_{i 0}$ corresponds to household $i$ 's initial CLTV, and $C_{j t}^{H P A}$ corresponds to the cumulative amount of HPA experienced in town $j$ from the date of house purchase through time $t .^{28}$ We suspect the relationship between equity and foreclosure is non-linear. A borrower with positive home equity will always prefer to sell the home or refinance to extract that equity, rather than defaulting, while a borrower with negative equity will not have these options. Thus, we expect an increase in equity for a borrower in a position of negative equity to have a significantly different effect from an increase in equity for a borrower who has positive equity in his or her home. For this reason, we assume a specification that allows for the effect of equity on default to change, depending on the equity level of the borrower. To do this we specify equity as a linear spline, with six intervals: (- $\infty,-10 \%),[-10 \%$, $0 \%),[0 \%, 10 \%),[10 \%, 25 \%)$, and $[25 \%, \infty) .{ }^{29}$ Since we do not have detailed information regarding mortgage characteristics, we use variables that are aggregated to both the level of the Census block group, and the town. These variables include the unemployment rate of the town (BLS), the percentage of individuals in the Census block group where the home is located who have a high school diploma (2000 Census), the percentage of individuals with a college education in the Census block group (2000 Census), and the percentage of households with income below the poverty level (2000 Census). ${ }^{30}$

The estimated effects of the explanatory variables on the incidence of foreclosure are displayed in Table 5. The strongest effects come from the subprime purchase indicator and the race variables. Homeowners who use a subprime mortgage to finance a home purchase are approximately 5 times as likely to lose the home to foreclosure, other things being equal. We interpret this parameter as a correlation and do not assign a causal interpretation. It simply tells us the relative frequency of foreclosure for a subprime purchase borrower compared with the frequency for a borrower who uses a prime mortgage. This variable likely includes both omitted selection effects, since borrowers who use the subprime market have poor credit histories relative to other borrowers, and treatment effects, since interest rates in the subprime market are often significantly higher than rates in the prime market as a result of heightened credit risk, which results in higher payments, which, in turn, increase the likelihood of default. According to the model estimates, black households are more than 3 times as likely to experience a foreclosure as white households, while Hispanic households are about twice as likely to default. These effects likely reflect differences in credit histories, and

\footnotetext{
${ }^{28}$ This equity measure is somewhat crude, as it does not take into account amortization, cash-out refinances, or home improvements. See Foote, Gerardi, and Willen (2008b) for a more detailed discussion of the implication of these omissions on the estimates of the model.

${ }^{29}$ See Foote, Gerardi, and Willen (2008b) for a more detailed discussion of the selection of the intervals.

${ }^{30} \mathrm{We}$ also include a measure of nominal short-term interest rates (the 6-month LIBOR rate) to capture changes in monthly mortgage payments for homeowners with adjustable-rate mortgages.
} 
thus credit scores, between minority households and white households, as well as differences in financial wealth. An interesting, and perhaps perplexing result is that according to the model, non-occupant owners do not default at higher rates than owner occupiers. However, we are modeling homeownership termination for multi-family properties, and it is likely that both owner occupiers and non-occupant owners in multi-families rely on rental income to help finance mortgage payments. One of the interesting estimation results from the sale hazard is the correlation between the subprime purchase indicator and the incidence of sale. The estimate is significant and positive, implying that subprime ownerships sell with greater frequency than their prime counterparts. This result provides support for the discussion of homeownership gross flows and net flows in the previous section. ${ }^{31}$

Because housing equity $E_{i t}$ is estimated with a spline, it is easier to see the estimated effects in a graph than in a table of coefficient estimates. Figure 7 plots the predicted foreclosure hazard as a function of equity. The covariates for a baseline, black, subprime purchase ownership have have been set to their sample averages. The takeaway from the figure is that increases in $E_{i t}$ have extremely large negative effects on foreclosures for the range of equity values between -50 and +25 percent of the purchase mortgage. For ownerships with nominal equity values above 25 percent, further increases in equity have a much smaller effect on the foreclosure hazard. The kink in the relationship occurs at 25 percent rather than zero, likely because of the potential transactions costs involved in selling a property, including the real estate brokerage commission (usually 6 percent of the sale price) as well as moving expenses. The shape of this relationship suggests that linear probability models, as well as probit and logit models that attempt to model the effect of equity on foreclosure using only a single parameter, as opposed to a spline, should be viewed with skepticism.

With the estimates of the model in hand, we perform some counterfactual simulations to show exactly how important a role HPA plays in the prevalence of Massachusetts foreclosures. We concentrate on multi-family ownerships that began in 2005, which we refer to as the 2005 vintage. We begin by calculating predicted foreclosures for this vintage, using the parameter estimates from the model and compare it with the actual number of foreclosures that occurred for this vintage. Figure 8 displays this exercise. The dashed line is the actual cumulative foreclosure percentage of the 2005 vintage, while the red line is the model's predicted percentage given the values of the explanatory variables. The model slightly over-predicts foreclosures, by a little more than 1 percentage point. Next, we compute predicted foreclosures for the 2005 vintage, assuming house price outcomes for two

\footnotetext{
${ }^{31}$ For brevity, we do not display all of the parameter estimates of the foreclosure and sale hazards in Table 5. The remaining parameter estimates are not surprising and are largely consistent with economic intuition. The results are available from the authors upon request.
} 
different vintages - the 1990 and 2002 vintages of multi-family homes. The bottom panel of Figure 5 shows the evolution of house prices for multi-family properties in Massachusetts. It is clear from this figure that prices fell by much more for the 1990 vintage than for the 2005 vintage. By 1994, multi-family housing prices had fallen by approximately 40 percent on average for the 1990 vintage. In contrast, prices rose by more than 50 percent over four years for the 2002 vintage. The results of this counterfactual exercise are quite dramatic. The blue line in Figure 8 displays the cumulative predicted foreclosures from the 2005 vintage when 1990 house price outcomes are substituted. The model predicts that by 2007:Q4, approximately 17 percent of the ownerships would end in foreclosure; this is a huge increase from the 10 percent it predicted using 2005 prices. In contrast, the model predicts fewer than 2 percent cumulative foreclosures for the 2005 vintage using 2002 house price outcomes (green line).

\section{Conclusion: Policy Implications}

The outlook for inner-city neighborhoods is somewhat bleak. As we have shown, they face an environment of falling house prices with a set of homeowners particularly ill-suited to handle them. We now argue, however, that the sheer depth of the problem actually allows for policy options, both related to the current crisis, and going forward, that would likely be impossible to implement with better situated borrowers.

Specifically, many commentators have recently argued that lenders should eliminate negative equity for borrowers in such a position by writing down a portion of the principal balance on their loans. ${ }^{32}$ The argument runs that such a plan benefits the lender as well as the borrower because the new principal balance exceeds the yield from foreclosure, once one takes into account the costs of foreclosure. Many commentators have argued that this solution is so obvious that one wonders why lenders do not implement it on a large scale. In the following discussion we show why lenders have not engaged in such a policy as a matter of course, but we also argue that for multi-family properties in the inner city, such a scheme might work.

There is a serious flaw in the logic of principal reduction. To see why, it is useful to think of two mistakes a lender could make. One mistake is to not offer assistance to a borrower in distress. The lender loses here if the increased probability of foreclosure and the high costs incurred by foreclosure make inaction more costly than assistance. We call this scenario "Type I Error." But there is another mistake, often overlooked, which is to

\footnotetext{
${ }^{32}$ See Zingales (2008) and Geanakoplos and Koniak (2008).
} 
assist a borrower who does not need the help. The lender loses here because it receives less in repayment from a borrower who would otherwise have paid off the mortgage in full. We refer to this case as "Type II Error."

Type II error is precisely the reason that lenders rarely engage in principal reduction. One lender summed it up this way, "We are wary of the consequences of being known as a bank that forgives principal...we have not to date forgiven any principal." 33 Some have suggested that principal reduction would benefit investors, but that complex agreements between servicers and investors make such a policy infeasible. However, the evidence for this explanation is severely lacking. For example, Freddie Mac, which retains credit risk when it securitizes a mortgage, and thus has complete discretion over the disposition of troubled loans, rarely grants any loan modifications. Furthermore, for the instances in which it does offer assistance, few involve any "concessions" like principal or interest rate reductions. ${ }^{34}$

To illustrate our argument more formally, we follow Foote, Gerardi, and Willen (2008), who consider a lender with a borrower who owes $m$ dollars on a house currently worth $p_{h}$ dollars and who will default with probability $\alpha_{0}$, in which case the lender recovers $p_{h}$ less $\lambda$ dollars in foreclosure costs. A principal reduction scheme lowers the outstanding balance on the loan to $m^{*}<m$ and the probability of foreclosure to $\alpha_{1}<\alpha_{0}$. Some simple arithmetic shows that this scheme is profitable if:

$$
\text { Net Gain }=\underbrace{\left(\alpha_{0}-\alpha_{1}\right)}_{\begin{array}{c}
\text { Reduction in } \\
\text { foreclosure prob. }
\end{array}} \times \underbrace{\left(m^{*}-\left(p_{h}-\lambda\right)\right)}_{\begin{array}{c}
\text { Reduced } \\
\text { loss }
\end{array}}-\underbrace{\left(1-\alpha_{0}\right)}_{\begin{array}{c}
\text { Pct. repay with } \\
\text { mitigation }
\end{array}} \times \underbrace{\left(m-m^{*}\right)}_{\begin{array}{c}
\text { Reduced value of } \\
\text { the mortgage }
\end{array}} .
$$

The first term corresponds to the Type I error - if a foreclosure is prevented, the lender recovers $m^{*}$ rather than $p_{h}-\lambda$. The second term corresponds to the Type II error-borrowers who would have repaid in full, but take advantage of principal reduction to reduce their debt burden.

In Table 6, we use equation (2) to calculate Type I error, Type II error, and the net gain to principal reduction for different types of properties and borrowers. We assume that $\lambda$, the cost of foreclosure, is 30 percent of the original balance of the loan, which implies that if the borrower has 20 percent negative equity, then the lender will recover 50 percent of the loan in foreclosure. In the table, we consider four cases: a borrower who lives in a multi-family property who financed the purchase with a subprime mortgage, a borrower

\footnotetext{
33 "Bankers' view of the new Hope for Homeowners program," ABA Banking Journal, October 2008.

${ }^{34}$ In the third quarter of 2008, Freddie Mac performed approximately 8,500 loan modications. The majority of the modifications did not include concessions, but rather involved adding past due amounts to the loan balance or extending the term of the loan (10-Q, November 14, 2008, p. 82.)
} 
who lives in a multi-family property who initially obtained a prime mortgage, and both of these scenarios for a borrower who purchased a single-family property. We use the estimated parameters from our model to calculate predicted, cumulative foreclosure probabilities for a borrower in each these scenarios, over an eight-year horizon. We set the values of the other explanatory variables in the model to their sample means in the data. We assume a borrower from the 2005 vintage with 20 percent negative equity, and we assume that prices will be flat indefinitely going forward.

Our policy experiment here is to lower the principal so that the borrower moves from 20 percent negative equity to 10 percent positive equity. Types I and II error and net gains are measured as a percentage of the original loan balance.

The results from the table illustrate both the limits and the opportunities for principal reduction. For most groups, Type II error is large relative to Type I error. The reason is straightforward: most borrowers will repay their loan, even if they are in negative equity positions. For the subprime single-family borrower, a 33 percent foreclosure rate implies a 66 percent repayment rate.

One potential criticism of the above argument is that one could minimize Type II error by requiring proof that a borrower is likely to default. However, as a practical matter, this would be extremely difficult to enforce. Tax documents and even credit reports in many cases would not suffice, as many borrowers in need of assistance are likely suffering from very recent adverse events. Instead, policymakers would need to obtain and verify current information on income, wealth, employment status, and perhaps even more personal events, such as marital status. This would be extremely costly. Furthermore, the results from Table 6 suggest that even if qualification requirements reduced Type II error by half, principal reduction would still not make sense for three of the four groups.

The only group in Table 6 for which principal reduction makes economic sense is the multi-family, subprime borrower. In this case, Type I error is high because the reduction in foreclosures from principal reduction is extremely large (63 percent to 13 percent), while Type II error is small since the probability of foreclosure (in the absence of assistance) is so high.

What form such assistance takes is an open question. All the foregoing suggests is that the cost of reducing principal for owners of subprime mortgages on multi-family properties is small. Simply reducing principal, though, leaves marginal homeowners in place, who still have a high likelihood of foreclosure. In this particular instance, our non-structural estimation approach most likely overestimates the benefits of increasing equity in reducing foreclosures, meaning that our estimate of the post-treatment foreclosure probability is a lower bound. Thus, the appropriate policy response may be to work with the lender to 
find a new buyer who will pay off the reduced principal, perhaps a community organization, rather than reducing principal for the current borrower. 


\section{References}

Aaronson, D., 2000. A note on the benefits of homeownership. Journal of Urban Economics 47(3): 356-369.

Alba, R., Logan, J., and Bellair, P., 1994. Living with crime: The implications of racial/ethnic differences in suburban location. Social Forces 73: 395-434.

Apgar, W. and Herbert, C., 2005. Subprime lending and alternative financial service providers: A literature review and empirical analysis. Department of Housing and Urban Develpment.

Avery, R. B., Brevoort, K. P., and Canner, G. B., 2006. Higher-priced home lending and the 2005 HMDA data. Federal Reserve Board 92(3): A123-A166.

Calem, P., Gillen, K., and Wachter, S., 2004. The neighborhood distribution of subprime mortgage lending. Journal of Real Estate Finance and Economics 29(4): 393410.

Canner, G., Passmore, W., and Laderman, E., 1999. The role of specialized lenders in extending mortgages to lower-income and minority homebuyers. Federal Reserve Bulletin.

Case, K. and Marynchenko, M., 2002. Home price appreciation in low- and moderateincome markets. In Low-Income Homeownership: Examining the Unexamined Goal, ed, N.P. Retsinas and E.S. Belsky. Washington, DC: Brookings Institution Press.

Case, K. and Shiller, R., 1987. Prices of single family homes since 1970: New indexes for four cities. NBER Working Paper No. 2393.

Collins, W. and Margo, R., 1999. Race and home ownership, 1900 to 1990. NBER Working Paper No. 7277.

Cox, K., 1982. Housing tenure and neighborhood activism. Urban Affairs Quarterly 8: $107-129$.

Deng, Y., Quigley, J., and Order, R. V., 2000. Mortgage terminations, heterogeneity and the exercise of mortgage options. Econometrica 68(2): 275-307.

Dietz, R. and Haurin, D., 2003. The social and private micro-level consequences of homeownership. Journal of Urban Economics 54(3): 401-450.

DiPasquale, D. and Glaeser, E., 1999. Incentives and social capital: Are homeowners better citizens? Journal of Urban Economics 25(3): 401-450.

Dubin, R., 2008. Foreclosures in Cleveland. manuscript. 
Flavin, M. and Yamashita, T., 2000. Owner occupied housing and the composition of the household portfolio. American Economic Review 92(1): 345-362.

Foote, C., Gerardi, K., Goette, L., and Willen, P., 2008a. Just the facts: An initial analysis of subprime's role in the housing crisis. Journal of Housing Economics 17(4): 291-305.

Foote, C., Gerardi, K., and Willen, P., 2008b. Negative equity and foreclosure: Theory and evidence. Journal of Urban Economics 6(2): 234-245.

Geanakoplos, J. and Koniak, S., 2008. The best way to help homeowners - and the economy. Available at http://cowles.econ.yale.edu/gean/crisis/index.htm.

Genesove, D. and Mayer, C., 2001. Loss aversion and seller behavior: Evidence from the housing market. Quarterly Journal of Economics 116(4): 1233-1260.

Gerardi, K., Shapiro, A., and Willen, P., 2007. Subprime outcomes: Risky mortgages, homeownership experiences, and foreclosures. Federal Reserve Bank of Boston Working Paper 07-15.

Glaeser, E. and Sacerdote, B., 1999. Why is there more crime in cities? Journal of Political Economy 107: S225-S258.

Gramlich, E., 2004. Subprime mortgage lending: Benefits, costs, and challenges. Financial Services Roundtable Annual Housing Policy Meeting, Chicago, IL.

Gramlich, E., 2007. Subprime Mortgages America's Latest Boom and Bust. The Urban Institute Press, Washington, DC.

Green, R. and White, M., 1997. Measuring the benefits of homeowning: Effects on children. Journal of Urban Economics 41(3): 441-461.

Harding, J., Rosenblatt, E., and Yao, V., 2008. The contagion effect of foreclosed properties. Available at SSRN: http://ssrn.com/abstract=1160354.

Harvey, K. and Nigro, P., 2004. Do predatory lending laws influence mortgage lending? an analysis of the North Carolina predatory lending law. Journal of Real Estate Finance and Economics 29(4): 435-456.

Haurin, D. and Gill, H., 2002. The impact of transaction costs and the expected length of stay on homeownership. Journal of Urban Economics 51(3): 563-584.

Herbert, C. and Belsky, E., 2006. The homeownership experience of low-income and minority families: A review and synthesis of the literature. Department of Housing and Urban Develpment. 
Immergluck, D. and Smith, G., 1999. Two Setps Back: The Dual Mortgage Market, Predatory Lending, and the Undoing of Community Development. The Woodstock Institute, Chicago, IL.

Immergluck, D. and Smith, G., 2004. Risky business - an econometric analysis of the relationship between subprime lending and neighborhood foreclosures. Chicago, IL: The Woodstock Institute.

Immergluck, D. and Smith, G., 2006. The impact of single-family mortgage foreclosures on neighborhood crime. Housing Studies 21(6): 851-866.

Lundberg, P. and Skedinger, P., 1998. Capital gains taxation and residential mobility in Sweden. Journal of Public Economics 67(3): 399-419.

Mayer, C., Pence, K., and Sherlund, S., 2008. The rise in mortgage defaults: Facts and myths. Journal of Economic Perspectives page forthcoming.

Mayer, C. J. and Pence, K., 2008. Subprime mortgages: What, where, and to whom? Working Paper 14083, National Bureau of Economic Research.

Mayer, N., 1981. Rehabilitation decisions in rental housing: An empirical analysis. Journal of Urban Economics 10(1): 76-94.

McCarthy, G., Zandt, S. V., and Rohe, W., 2001. The economic benefits and costs of homeownership: A critical assessment of the research. Research Institute for Housing America, Washington, (DC Working Paper 01-02).

Moreno, A., 1995. The cost-effectiveness of mortgage foreclosure prevention. Minneapolis: Family Housing Fund.

N.H.S., 2004. Preserving homeownership: Community-development implications of the new mortgage market. Chicago, IL: Neighborhood Housing Services of Chicago.

Pennington-Cross, A., 2002. Subprime lending in the primary and secondary markets. Journal of Housing Research 13(1): 31-50.

Pennington-Cross, A. and Ho, G., 2006. The termination of subprime hybrid and fixed rate mortgages? Federal Reserve Bank of St. Louis Working Paper Series 2006042A.

Pennington-Cross, A. and Nichols, J., 2000. Credit history and the fha conventional choice. Real Estate Economics 28(2): 307-336.

Quigley, J., 1987. Interest rate variations, mortgage prepayments and household mobility. Review of Economics and Statistics 49(4): 636-643. 
Rogers, W. and Winter, W., 2008. The impact of foreclosures on neighboring housing sales.

Rohe, W. and Stegman, M., 1994. The impact of homeownership on the social and political involvment of low-income people. Urban Affairs Quarterly 30: 152-172.

Rossi, P. and Weber, E., 1996. The social benefits of homeownership: Empirical evidence from national surveys. Housing Policy Debate 7: 1-35.

Sinai, T. and Souleles, N., 2005. Owner-occupied housing as a hedge against rent risk. Quarterly Journal of Economics 120(2): 763-789.

Zingales, L., 2008. Plan b. Economists' Voice 5(6): 4. 
Table 1: Match Statistics for HMDA and Warren Group Data Merge

Purchases

\begin{tabular}{|c|c|c|c|c|c|}
\hline \multirow[t]{2}{*}{ Year } & \multirow{2}{*}{$\begin{array}{c}\text { \# Purchases } \\
\text { (Warren Data) }\end{array}$} & \multicolumn{2}{|c|}{ HMDA Ownership Matches } & \multicolumn{2}{|c|}{ HMDA Race Matches } \\
\hline & & $\#$ & $\%$ purchases & $\#$ & $\%$ purchases \\
\hline 1998 & 113,623 & 80,120 & 70.5 & 74,781 & 65.8 \\
\hline 1999 & 114,990 & 82,749 & 72.0 & 76.625 & 66.6 \\
\hline 2000 & 107,621 & 79,091 & 73.5 & 72,894 & 67.7 \\
\hline 2001 & 103.302 & 77,267 & 74.8 & 69,844 & 67.6 \\
\hline 2002 & 107,320 & 78,817 & 73.4 & 70,704 & 65.9 \\
\hline 2003 & 109,941 & 77,281 & 70.3 & 69.027 & 62.8 \\
\hline 2004 & 121,497 & 89,117 & 73.3 & 80,201 & 66.0 \\
\hline 2005 & 116,246 & 84,987 & 73.1 & 77,475 & 66.6 \\
\hline 2006 & 98,133 & 70,718 & 72.1 & 63,842 & 65.1 \\
\hline
\end{tabular}

Sales

\begin{tabular}{c|c|cc|cc}
\hline \hline Year & \multirow{2}{*}{ \# Sales } & \multicolumn{2}{|c|}{ HMDA Ownership Matches } & \multicolumn{2}{c}{ HMDA Race Matches } \\
\cline { 3 - 6 } & (Warren Data) & $\#$ & \% sales & $\#$ & \% sales \\
\hline 1998 & 110,595 & 2,352 & 2.1 & 2,159 & 2.0 \\
1999 & 112,701 & 11,003 & 9.8 & 9,884 & 8.8 \\
2000 & 105,951 & 17,660 & 16.7 & 15,719 & 14.8 \\
2001 & 102,119 & 23,355 & 22.9 & 20,712 & 20.3 \\
2002 & 106,236 & 31,729 & 29.9 & 27,931 & 26.3 \\
2003 & 109,254 & 41,005 & 37.5 & 36,073 & 33.0 \\
2004 & 120,763 & 51,165 & 42.4 & 45,285 & 37.5 \\
2005 & 115,301 & 50,146 & 43.5 & 44,841 & 38.9 \\
2006 & 95,978 & 42,139 & 43.9 & 37,928 & 39.5 \\
2007 & 81,493 & 36,471 & 44.8 & 33,082 & 40.6 \\
\hline \hline
\end{tabular}

Foreclosures

\begin{tabular}{c|c|cc|cc}
\hline \hline Year & \# Foreclosures & \multicolumn{2}{|c|}{ HMDA } & Ownership Matches & \multicolumn{2}{|c}{ HMDA Race Matches } \\
\cline { 3 - 6 } & (Warren Data) & $\#$ & \% foreclosures & $\#$ & \% foreclosures \\
\hline 1998 & 2,816 & 13 & 0.5 & 12 & 0.4 \\
1999 & 2,078 & 91 & 4.4 & 75 & 3.6 \\
2000 & 1,483 & 198 & 13.4 & 168 & 11.3 \\
2001 & 1,107 & 312 & 28.2 & 271 & 24.5 \\
2002 & 983 & 393 & 40.0 & 342 & 34.8 \\
2003 & 590 & 304 & 51.5 & 254 & 43.1 \\
2004 & 652 & 354 & 54.3 & 286 & 43.9 \\
2005 & 966 & 625 & 64.7 & 523 & 54.1 \\
2006 & 2,785 & 2,279 & 81.8 & 1,992 & 71.5 \\
2007 & 7,053 & 5,995 & 85.0 & 5,341 & 75.7 \\
\hline \hline
\end{tabular}


Table 2: Cross-race Transitions

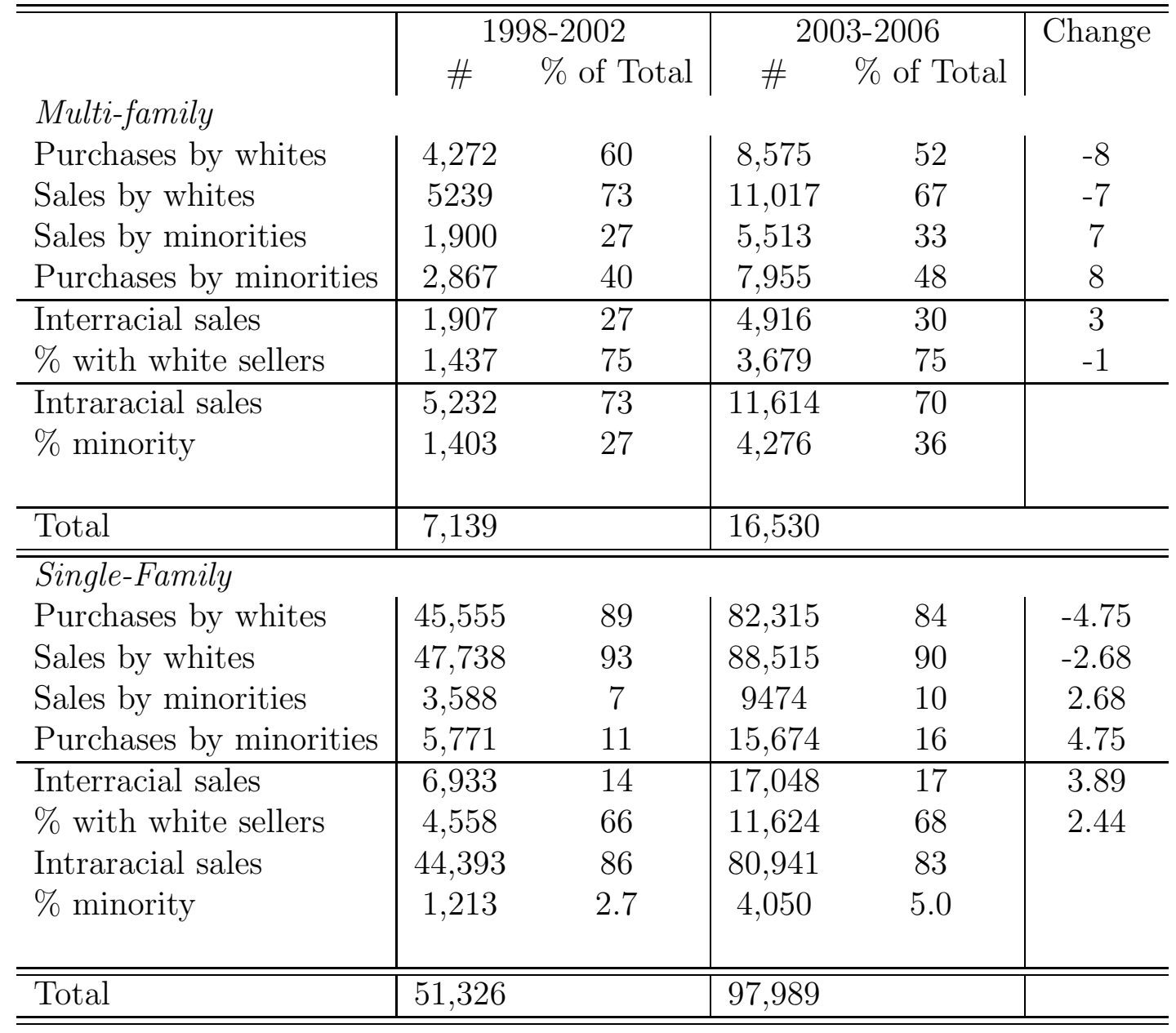


Table 3: Subprime Purchase Statistics by Race

\begin{tabular}{|c|c|c|c|c|c|c|c|c|c|}
\hline \multirow[t]{2}{*}{ Year } & \multicolumn{3}{|c|}{ White } & \multicolumn{3}{|c|}{ Black } & \multicolumn{3}{|c|}{ Hispanic } \\
\hline & $\begin{array}{c}\text { foreclosure rate } \\
\text { (cum \%) }\end{array}$ & $\begin{array}{c}\text { DTI } \\
\text { (median) }\end{array}$ & $\begin{array}{c}\text { CLTV } \\
\text { (median) }\end{array}$ & $\begin{array}{c}\text { foreclosure rate } \\
\text { cum \%) }\end{array}$ & $\begin{array}{c}\text { DTI } \\
\text { (median) }\end{array}$ & $\begin{array}{c}\text { CLTV } \\
\text { (median) }\end{array}$ & $\begin{array}{c}\text { foreclosure rate } \\
(\text { cum } \%)\end{array}$ & $\begin{array}{c}\text { DTI } \\
\text { (median) }\end{array}$ & $\begin{array}{c}\text { CLTV } \\
\text { (median) }\end{array}$ \\
\hline 1998 & 4.1 & 2.05 & 0.85 & 8.5 & 2.17 & 0.90 & 7.1 & 2.08 & 0.90 \\
\hline 1999 & 2.5 & 2.07 & 0.84 & 9.2 & 1.97 & 0.90 & 5.1 & 2.25 & 0.85 \\
\hline 2000 & 5.4 & 2.19 & 0.85 & 8.1 & 2.25 & 0.85 & 8.1 & 2.16 & 0.90 \\
\hline 2001 & 5.2 & 2.36 & 0.90 & 8.7 & 2.52 & 0.90 & 8.3 & 2.28 & 0.90 \\
\hline 2002 & 4.8 & 2.63 & 0.90 & 8.9 & 2.91 & 0.92 & 6.2 & 3.13 & 0.95 \\
\hline 2003 & 5.1 & 2.97 & 0.95 & 8.6 & 3.43 & 0.95 & 6.6 & 3.45 & 0.95 \\
\hline 2004 & 6.6 & 3.24 & 0.95 & 12.9 & 3.74 & 0.98 & 10.4 & 3.64 & 1.00 \\
\hline 2005 & 6.5 & 3.31 & 1.00 & 15.0 & 3.81 & 1.00 & 10.3 & 3.79 & 1.00 \\
\hline 2006 & 4.1 & 3.11 & 0.95 & 10.2 & 3.56 & 1.00 & 6.8 & 3.59 & 1.00 \\
\hline
\end{tabular}

Table 4: Multi-family Purchases - Top 10 MA Cities/Towns

\begin{tabular}{|c|c|c|c|c|c|}
\hline & \multicolumn{2}{|c|}{$1998-2006$} & \multirow{2}{*}{$\begin{array}{l}2007 \text { population } \\
\text { rank }\end{array}$} & \multirow{2}{*}{$\begin{array}{l}1999 \text { Median Income } \\
\text { rank (descending order) }\end{array}$} & \multirow{2}{*}{$\begin{array}{c}1999 \% \text { of Non-White Households } \\
\text { rank (descending order) }\end{array}$} \\
\hline & \# purchases & $\%$ of total & & & \\
\hline Boston & 15,691 & 14.1 & 1 & 56 & 2 \\
\hline Springfield & 7,757 & 7.0 & 3 & 14 & 3 \\
\hline Worcester & 6,239 & 5.6 & 2 & 34 & 18 \\
\hline New Bedford & 3,921 & 3.5 & 7 & 3 & 19 \\
\hline Lynn & 3,914 & 3.5 & 6 & 55 & 5 \\
\hline Lawrence & 3,751 & 3.4 & 10 & 49 & 10 \\
\hline Brockton & 3,708 & 3.3 & 13 & 6 & 1 \\
\hline Lowell & 3,119 & 2.8 & 4 & 54 & 13 \\
\hline Somerville & 2,730 & 2.5 & 12 & 101 & 17 \\
\hline \multirow[t]{2}{*}{ Fall River } & 2,351 & 2.1 & 9 & 8 & 60 \\
\hline & 53,181 & 47.8 & - & - & - \\
\hline
\end{tabular}

Table 5: Either One Standard Deviation Change for Continuous Variables or 0/1 Change for Dichotomous Variables.

\begin{tabular}{l|c|c|c}
\hline \hline & & Default & Sale \\
\cline { 3 - 4 } & $(+/-)$ std. dev. & factor change hazard & factor change hazard \\
\hline DTI & 1.68 & 1.38 & 1.13 \\
Unemployment Rate & 1.89 & 1.13 & 1.01 \\
Subprime purchase indicator &. & 5.14 & 1.47 \\
Black &. & 3.35 & 0.91 \\
Hispanic &. & 2.03 & 1.04 \\
Non-owner Occupied &. & 0.95 & 1.40 \\
\hline \hline
\end{tabular}


Table 6: Benefits to a Lender of Principal Reduction. Type I error measures the cost of not assisting borrowers who need help. Type II error measures the cost of assisting borrowers who do not need help. The net gain to the lender, as shown in Section 6, equals the difference between Type I and Type II error. Benefits are measured as a percentage of the original loan balance.

\begin{tabular}{ll|cc|cc|cc|c}
\hline \hline \multirow{2}{*}{$\begin{array}{c}\text { Property } \\
\text { Type }\end{array}$} & \multicolumn{2}{|c|}{ Hefore } & \multicolumn{4}{c}{ After Principal Reduction } \\
Status & Equity & Prob. & Equity & Prob. & Errors & Net \\
ingle-Family & Prime & -20 & 4 & 10 & 2 & 0 & 26 & -25.8 \\
Multi-Family & Prime & -20 & 17 & 10 & 3 & 3 & 23 & -19.3 \\
Single-Family & Subprime & -20 & 33 & 10 & 9 & 5 & 18 & -12.7 \\
Multi-Family & Subprime & -20 & 63 & 10 & 13 & 11 & 10 & 1.0 \\
\hline \hline
\end{tabular}


Figure 1: Home Purchases, 1998-2006. Figures show total number of purchases (in thousands) in our matched-sample of purchase-and-sale deeds and HMDA loans.
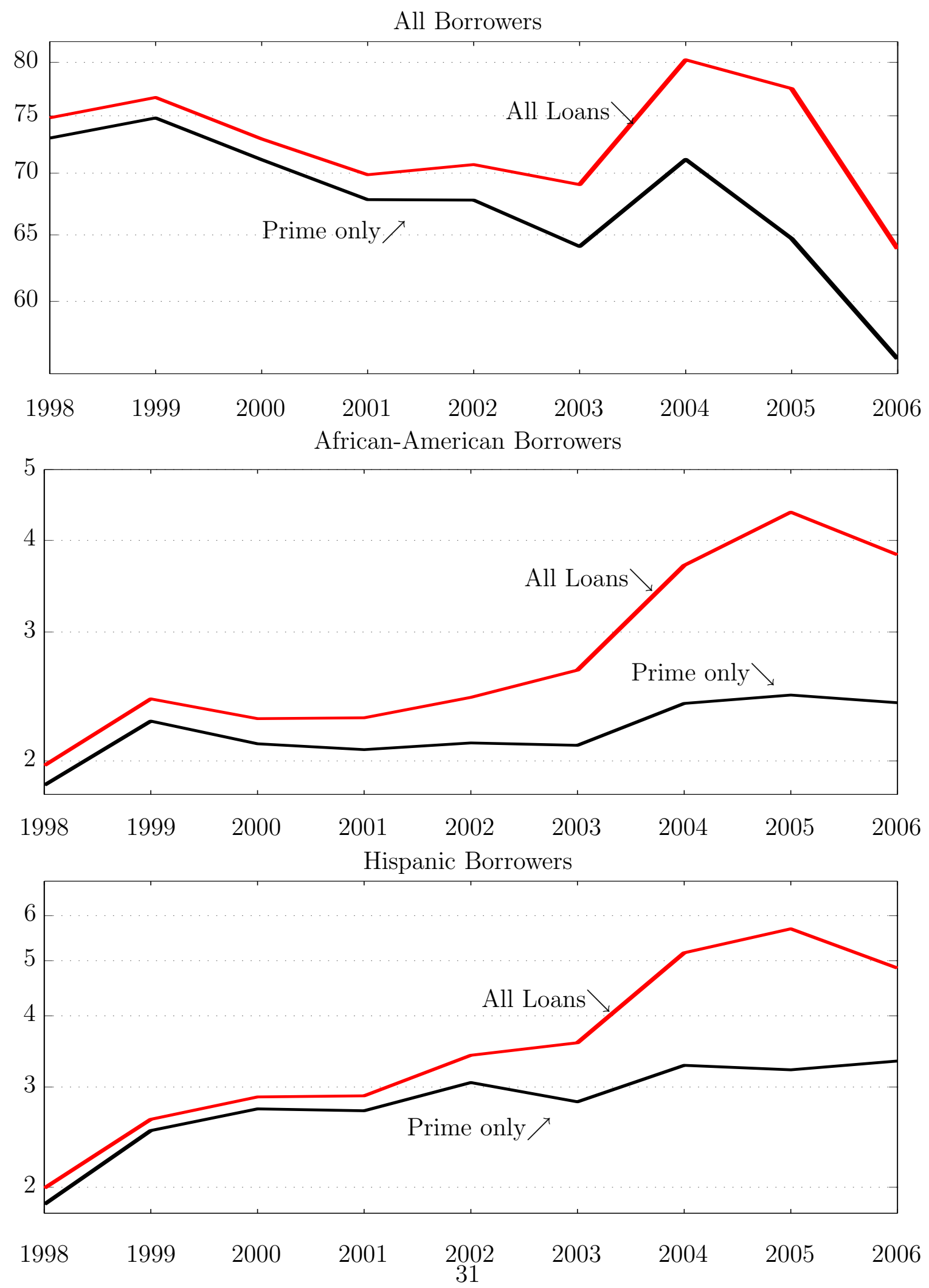
Figure 2: Subprime Purchases: Boston Minority Neighborhoods

\section{8-2002}

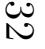
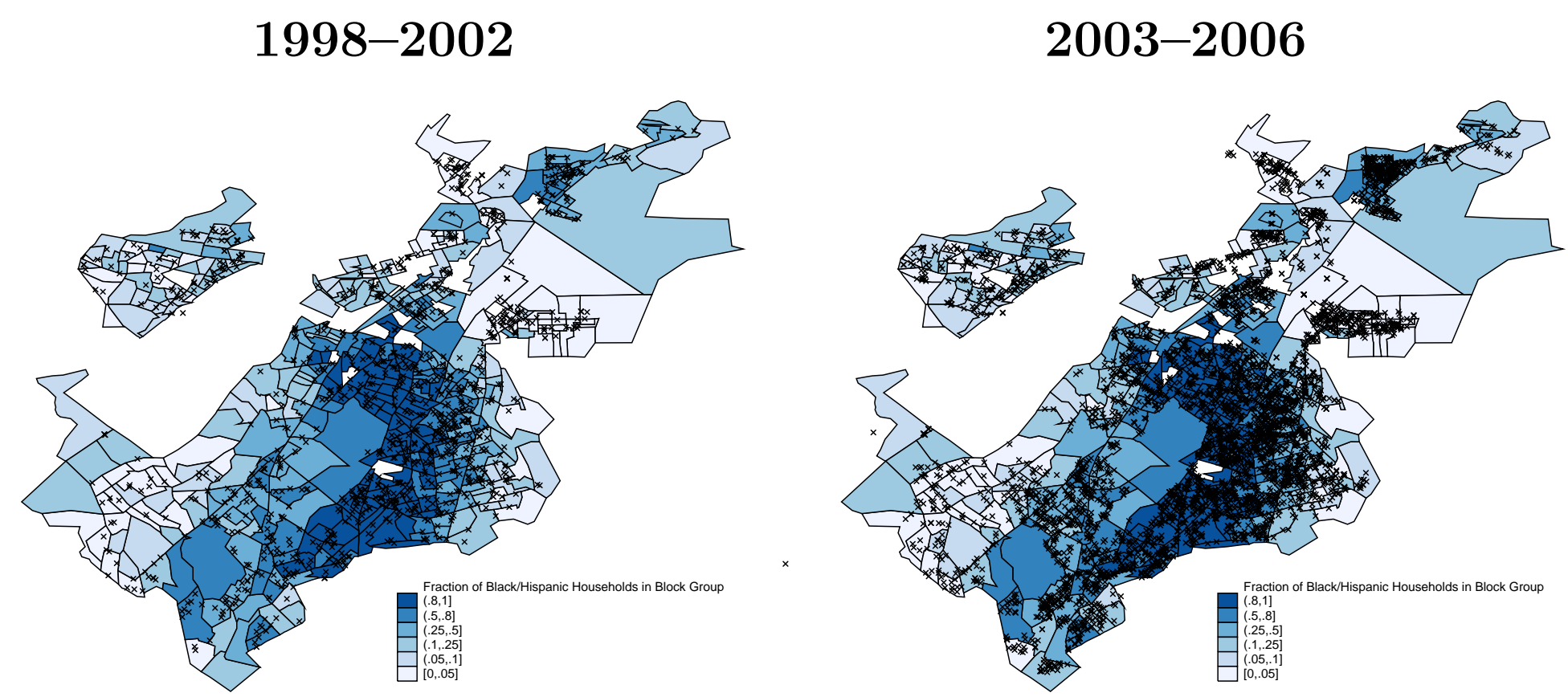
Figure 3: Gross and Net Flows into Homeownership, 1999-2007

\section{African-Americans}

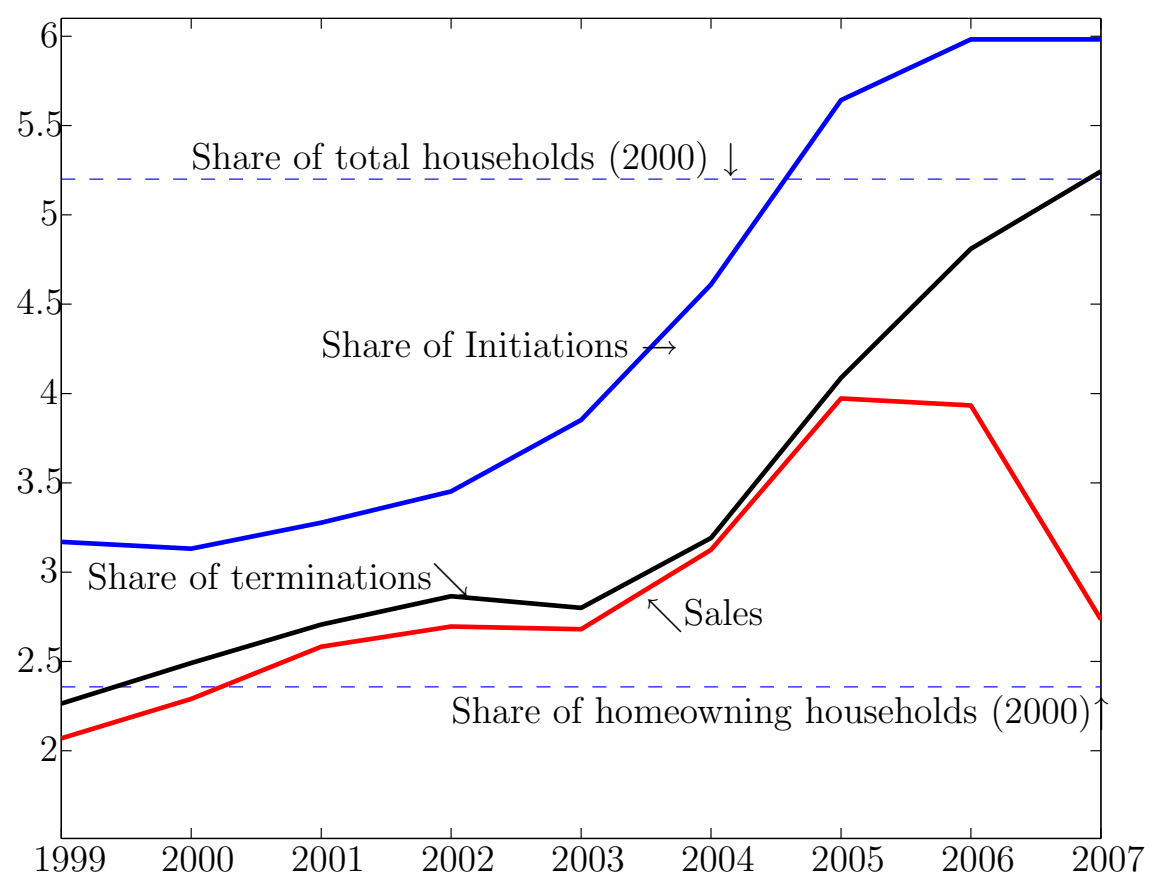

\section{Hispanics}

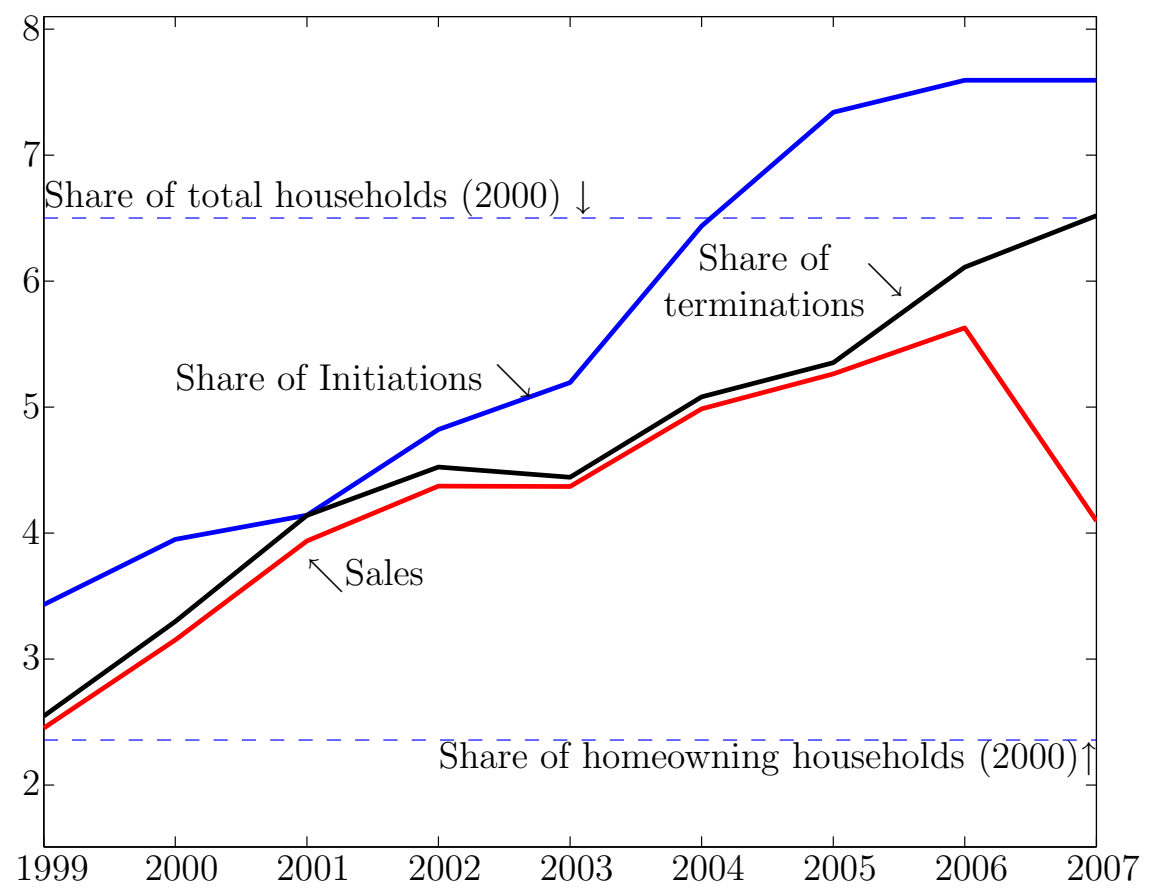


Figure 4: Foreclosures: Boston Minority Neighborhoods

\section{2}

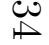

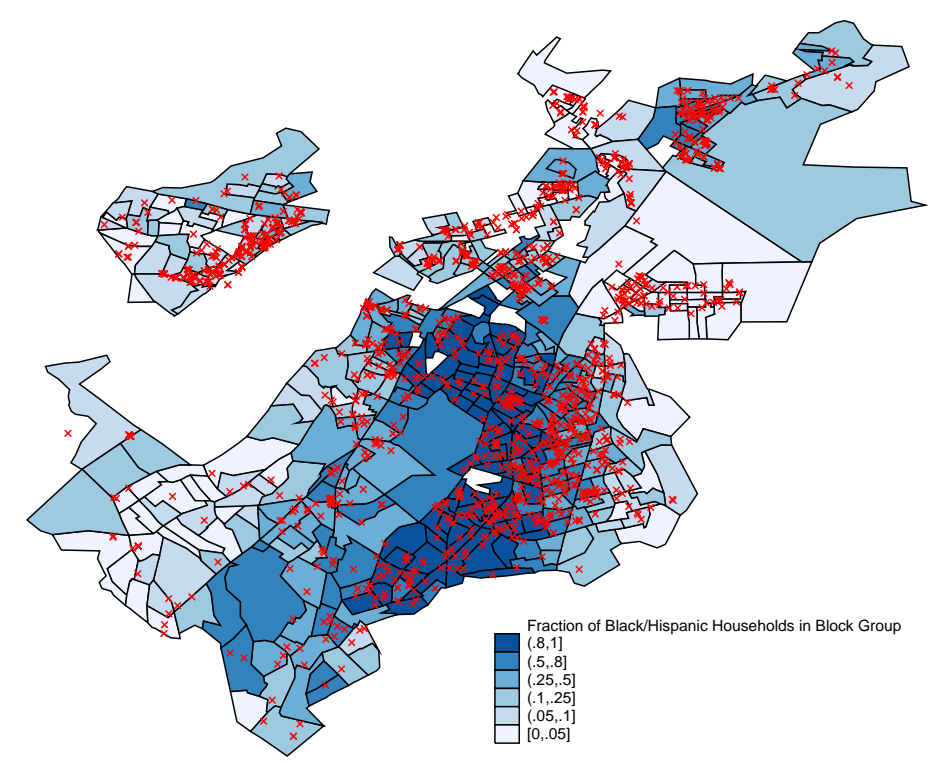

2007

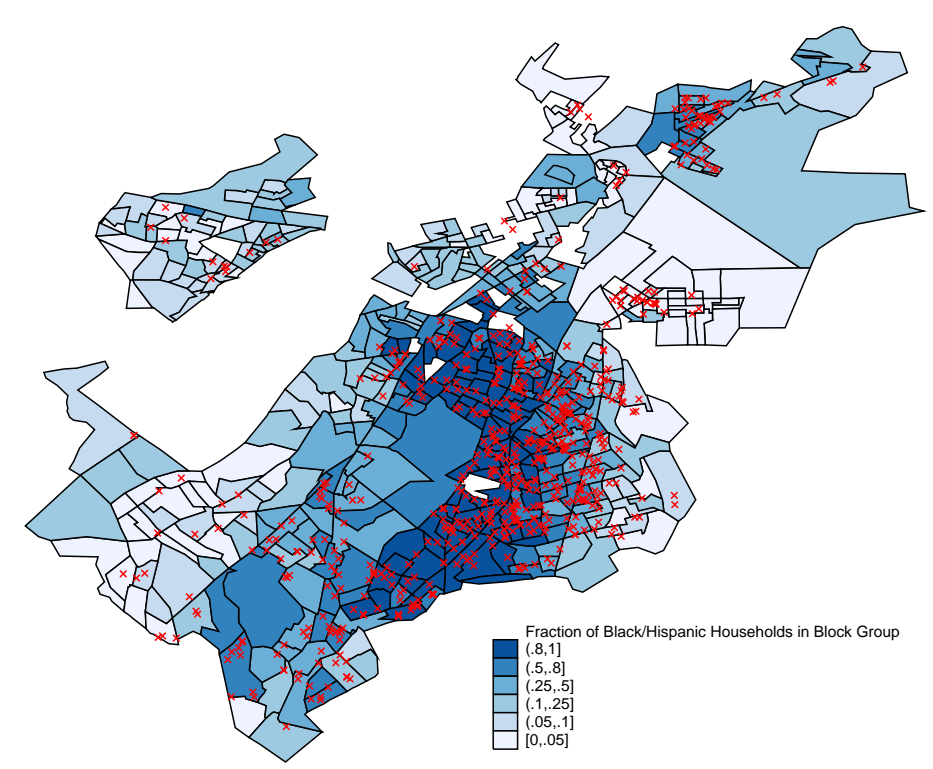


Figure 5: House Prices and Multi-family Foreclosures. Foreclosures are measured in units of housing affected. House prices are repeat-sales indexes calculated by the authors as described in the text.

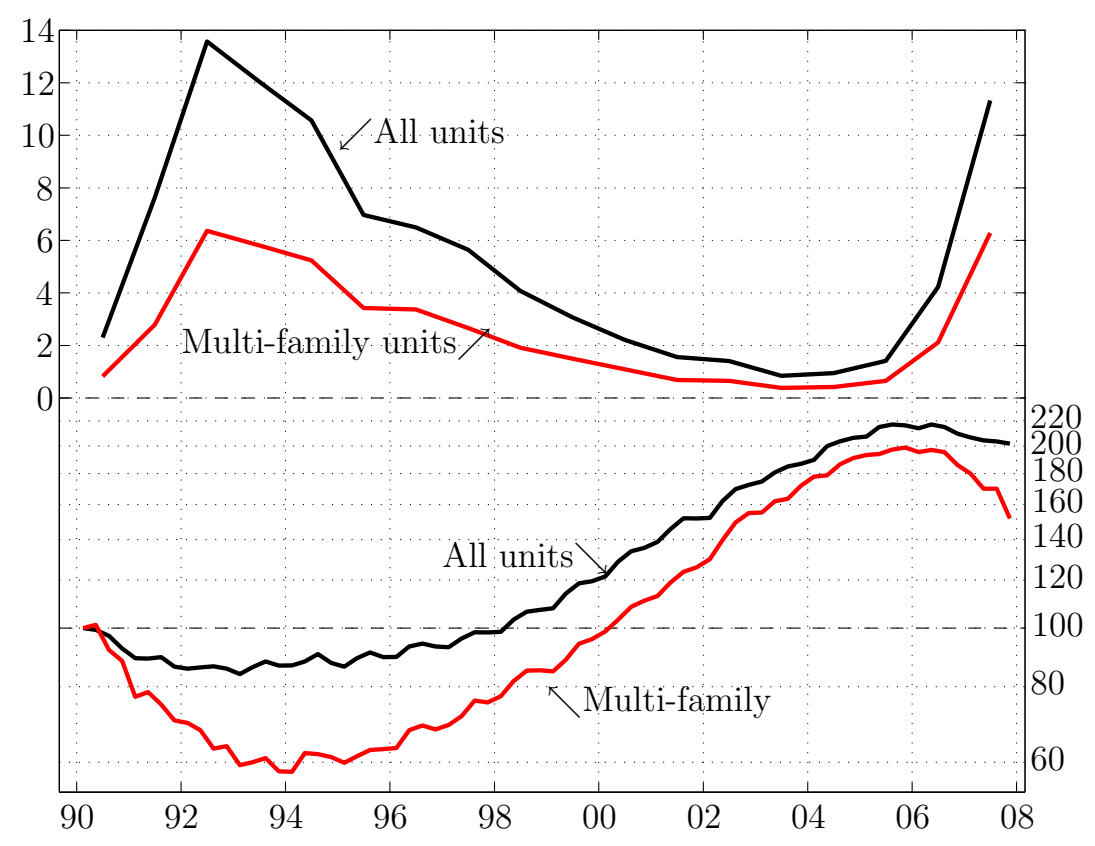

Figure 6: Purchases of Multi-Family Properties (2006)

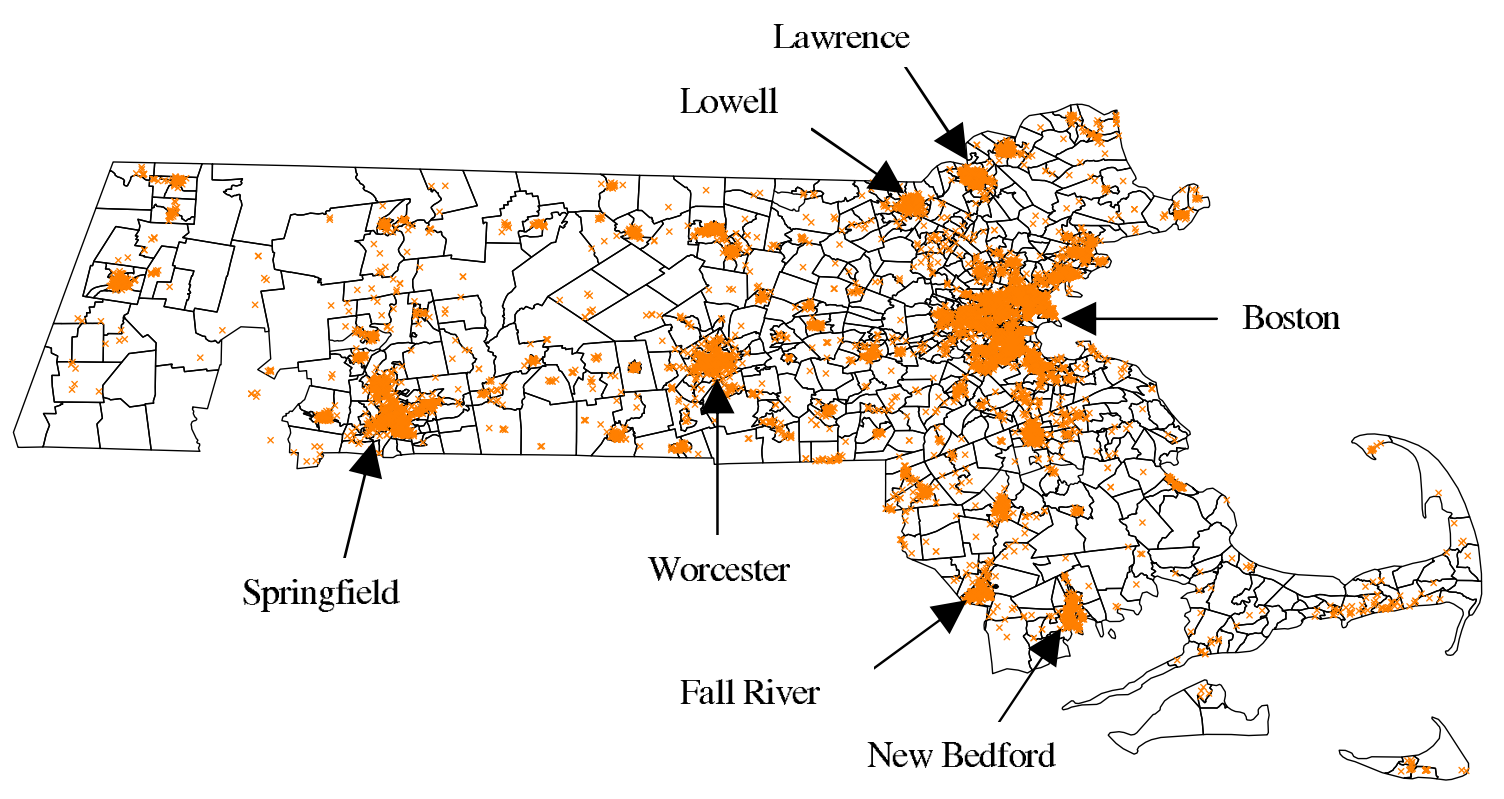


Figure 7: Estimated effect of equity on the foreclosure hazard for multi-family buyers

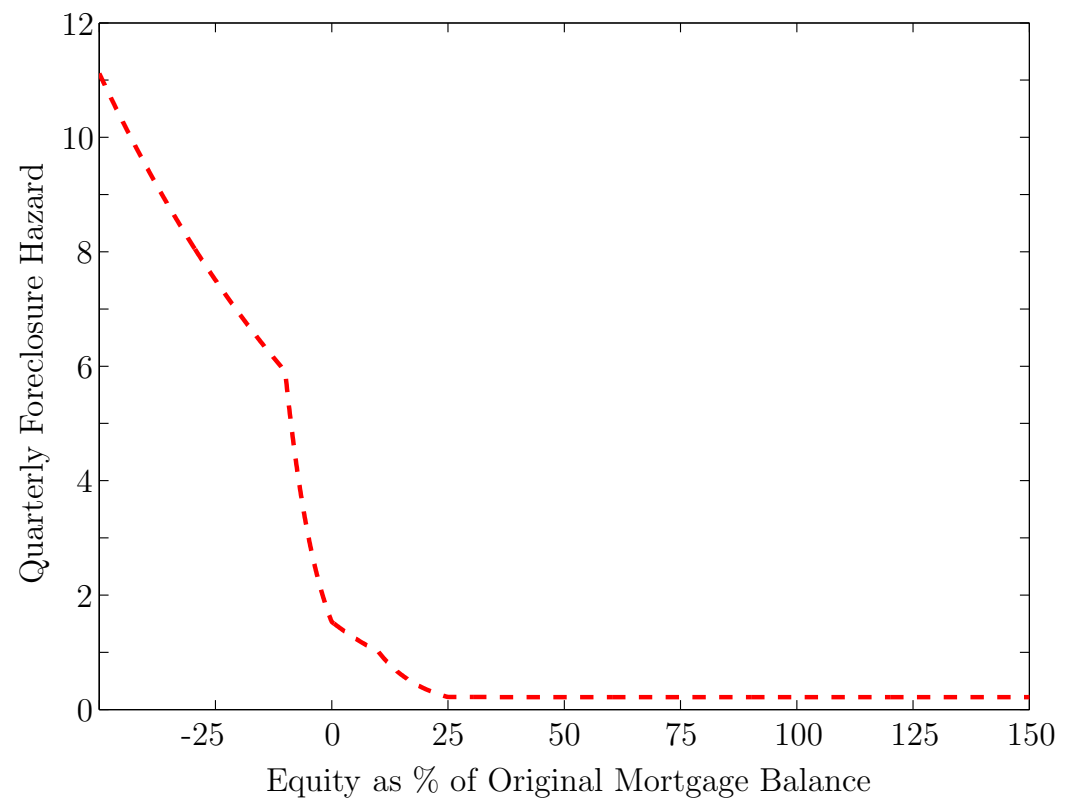


Figure 8: 2005 vintage Multi-family foreclosures

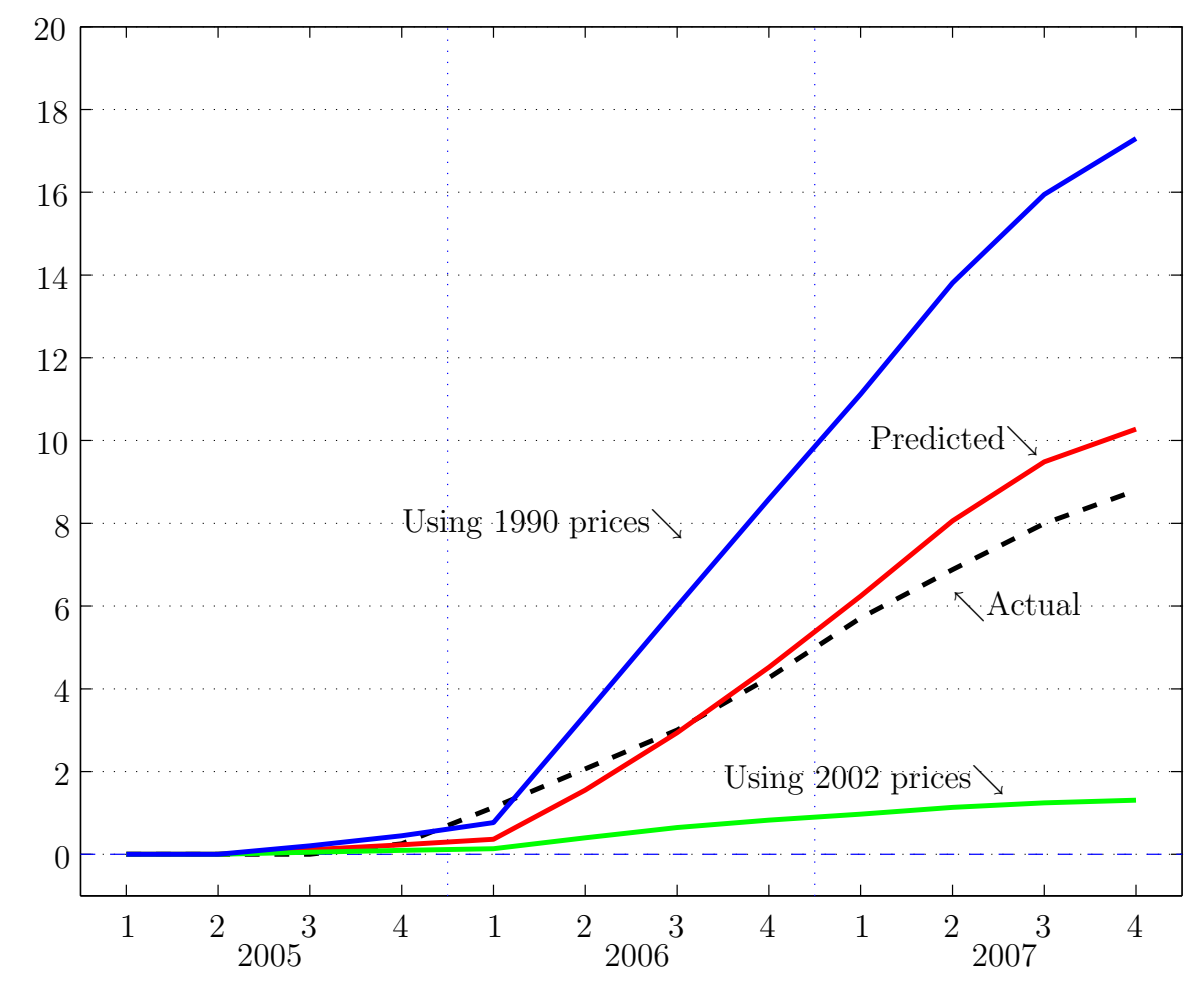

